\title{
IZLOŽBA OSTAVŠTINA IVANA KUKULJEVIĆA \\ SAKCINSKOG IZ ARHIVA I KNJIŽNICE HRVATSKE \\ AKADEMIJE ZNANOSTI I UMJETNOSTI
}

\author{
THE EXHIBITION THE LEGACY OF IVAN \\ KUKULJEVIĆ SAKCINSKI IN THE ARCHIVE AND THE LIBRARY \\ OF THE CROATIAN ACADEMY OF SCIENCES AND ARTS
}

\section{Nataša Daničić}

Knjižnica Hrvatske akademije znanosti i umjetnosti ndanicic@hazu.hr

Dina Mašina

Knjižnica Hrvatske akademije znanosti i umjetnosti dinam@hazu.hr

Tamara Runjak

Knjižnica Hrvatske akademije znanosti i umjetnosti trunjak@hazu.hr

UDK / UDC 061.4:021.7 Kukuljević Sakcinski, I. Izvorni znanstveni rad / Original scientific paper Prihvaćeno / Accepted: 26. 4. 2017

\section{Sažetak}

Općeznanstvena Knjižnica Hrvatske akademije znanosti i umjetnosti svoj atraktivni prostor redovito obogaćuje prigodnim izložbama kojima promovira bogat i raznovrstan knjižni fond. Povodom obilježavanja 200. godišnjice rođenja Ivana Kukuljevića Sakcinskog (1816.-1889.), jedne od najznačajnijih i nezaobilaznih osoba u modernoj hrvatskoj povijesti 19. st., Knjižnica je u suradnji s Arhivom HAZU organizirala izložbu pod nazivom Ostavština Ivana Kukuljevića Sakcinskoga iz Arhiva i Knjižnice Hrvatske akademije znanosti i umjetnosti : izložba povodom 200. godišnjice rođenja. Najveći dio izložbe čini Kukuljevićeva knjižnica koja broji 12000 jedinica građe, a danas se

Vjesnik bibliotekara Hrvatske 60, 1(2017), 47-64

ISSN 0507-1925

(C) VBH 2017. 
čuva dijelom u Akademijinoj Knjižnici, dijelom u Akademijinu Arhivu. Kronološko-tematskom strukturom izložbe nastojalo se sažeto prikazati Kukuljevićev iznimno bogat život i djelovanje, dati pregled njegovih radova na gotovo svim područjima znanosti i umjetnosti te prikazati je kada i na koji način došao do tako bogate i vrijedne knjižnice. Knjižnica HAZU, otvorena za najšire skupine korisnika, putem ove izložbe stekla je brojne nove članove, posjetitelje izložbe, koji su se prigodom razgledavanja ostavštine istaknutog i zaslužnog Hrvata upoznali s njezinim prostorom i zbirkama.

Ključne riječi: Knjižnica HAZU - izložbeni prostor, Ivan Kukuljević Sakcinski život i djelo, Ivan Kukuljević Sakcinski - ostavština, Arhiv HAZU

\section{Summary}

The General Science Library of the Croatian Academy of Sciences and Arts regularly enriches its attractive space with exhibitions on various important occasions which promote its rich and varied book collections. In order to mark the 200th anniversary of the birth of Ivan Kukuljević Sakcinski (1816-1889), one of the most significant and eminent persons in the modern Croatian history, the Library, in cooperation with the Archive of the Academy, organized an exhibition titled The Legacy of Ivan Kukuljevic Sakcinski in the Archive and the Library of the Croatian Academy of Sciences and Arts: exhibition on the occasion of the 200th anniversary of his birth. The largest part of the exhibition consists of Kukuljević's private library which contains 12,000 volumes, one part of which is kept in the Academy Library and the other in the Academy Archive. Chronological and thematic structure of the exhibition was intended to summarize Kukuljević's very rich life and work, to provide an overview of his work in almost all areas of sciences and arts, and to show when and how he acquired such a rich and valuable collection. With this exhibition, the Academy Library, open to the widest group of users, has gained a large number of new members, visitors of the exhibition, who had the opportunity to see the legacy of this distinguished and meritorious Croat and to get acquainted with the Library space and collections.

Keywords: Library of the Croatian Academy of Sciences and Arts - exhibition space, Ivan Kukuljević Sakcinski - life and work, Ivan Kukuljević Sakcinski - legacy, Archive of the Croatian Academy of Sciences and Arts

\section{Uvod}

Knjižnica Hrvatske akademije znanosti i umjetnosti posljednjih godina aktivno se uključila u razne kulturne manifestacije (poput Noći muzeja, Noći knjige, Dana otvorenih vrata HAZU, Dana gradske četvrti Donji grad, Dana grada 
Zagreba i dr.) kako bi na taj način još više privukla građane i prezentirala im ne samo bogatu kulturnu baštinu koju brižno čuva nego i današnji aktivni rad svojih djelatnika knjižničara. Vođena tom idejom, Knjižnica redovito u svojim prostorima postavlja prigodne i tematske izložbe s reprezentativnom građom iz svog fonda. Vrlo često izložbe prate znanstvene skupove priređene u čast neke istaknute osobe ili povodom obljetnica rođenja, smrti itd. koje organizira Hrvatska akademija znanosti i umjetnosti, a koji se održavaju u velikoj dvorani smještenoj u zgradi Knjižnice.

Ove je godine Akademija, odnosno njezin Zavod za znanstveni rad u Varaždinu u suradnji s Maticom hrvatskom Ogranak Varaždin i Turističkom zajednicom grada Varaždinske toplice, 25. svibnja organizirala jednodnevni znanstveni skup pod nazivom Ivan Kukuljević Sakcinski (1816.-1889.) u povodu 200. godišnjice rođenja u Varaždinu, mjestu Kukuljevićeva rođenja. Tim je povodom Knjižnica HAZU u suradnji s Arhivom HAZU 30. svibnja postavila u predvorju veliku izložbu pod nazivom Ostavština Ivana Kukuljevića Sakcinskoga iz Arhiva i Knjižnice Hrvatske akademije znanosti i umjetnosti : izložba povodom 200. godišnjice rođenja i na taj način prigodno obilježila 200 godina od rođenja istaknutog hrvatskog domoljuba Ivana Kukuljevića Sakcinskoga (1816.-1889.), jedne od najznačajnijih i nezaobilaznih osoba u modernoj hrvatskoj povijesti 19. st. Izložba je trajala do 30. listopada 2016. godine.

\section{Općeznanstvena knjižnica kao izložbeni prostor}

Knjižnice, koje su oduvijek imale ulogu središta kulture, osim pohrane i ustupanja knjižne građe, nastoje osigurati pristup informacijama i obrazovati širok krug korisnika. Dok je izložba u muzeju temeljni i elementarni oblik prezentativne komunikacije u kojem sudjeluju muzejski predmeti, muzeografska pomagala i posjetitelji muzeja ${ }^{1}$, u knjižnici predstavlja jednu od sastavnica u nadgradnji osnovne knjižnične djelatnosti. Izlaganje knjižne građe kao izložbenih predmeta jedan je od najatraktivnijih i sve zastupljenijih oblika prezentacije rada knjižnice i u funkciji je komunikacije s njezinim korisnicima (sadašnjim i potencijalnim), društvenom i kulturnom javnošću. ${ }^{2} \mathrm{~S}$ obzirom na to da je riječ o ustanovi čija primarna uloga nije izložbena, najveći dio posjetitelja izložbi čine korisnici knjižnice ("stalni posjetitelji"). Pri organizaciji i oblikovanju izložbi knjižničari se često služe teorijskom podlogom, alatima i praksom drugih struka kao što su arhivistička, muzejska i umjetnička.

\footnotetext{
1 Maroević, Ivo. Uvod u muzeologiju. Zagreb : Filozofski fakultet Sveučilišta, Zavod za informacijske studije Odsjeka za informacijske znanosti, 1993. Str. 201.

2 Coplan, Kate. Effective library exhibits : how to prepare and promote good displays. New York, NY : Oceana publications, 1958. Str. 21.
} 
Općeznanstvena knjižnica Hrvatske akademije znanosti i umjetnosti svoj atraktivni prostor na Strossmayerovu trgu 14 u Zagrebu redovito obogaćuje prigodnim izložbama kojima promovira bogat i raznovrstan knjižni fond. Prostran izložbeni prostor smješten je u prizemlju zgrade, a na raspolaganju je jedanaest staklenih izložbenih vitrina s primjerenom rasvjetom i specijalna Gaylord-vitrina za staru knjigu ${ }^{3}$, izrađena prema najvišim muzejskim standardima. Neke izložbe knjižnica priređuje samostalno, a kod postavljanja većih izložbi česta je suradnja sa stručnjacima raznih struka iz drugih zavoda i odsjeka Hrvatske akademije znanosti i umjetnosti. Redovito se izrađuju popratni izložbeni materijali: plakati, pozivnice, deplijani, letci ili manji katalozi s opisom izložaka.

\section{Ivan Kukuljević Sakcinski}

Ivan Kukuljević Sakcinski rođen je kao Ivan Donat Kazimir pl. Kukuljević Sakcinski u Varaždinu, 29. svibnja 1816. godine, kao deveto dijete Antonije rođ. pl. Labaš i Antuna, kraljevskog savjetnika, kasnije hrvatskog nuncija na ugarskom saboru u Požunu i ravnatelja svih škola u Hrvatskoj. ${ }^{4}$ U Zagrebu završava šestorazrednu gimnaziju te nakon toga upisuje studij filozofije ${ }^{5}$ koji prekida 1833. godine kako bi postao vojni časnik. ${ }^{6}$

Godine 1835., za vrijeme vojnog službovanja u Beču, Kukuljević upoznaje Ljudevita Gaja ${ }^{7}$ s kojim od 1837. godine surađuje u Danici ilirskoj. ${ }^{8}$ Godine 1842. na vlastito je traženje otpušten iz vojske te iste godine postaje velikim županom zagrebačkim. Sljedeće je godine prvi put izabran u Hrvatski sabor ${ }^{9}$ gdje iste, 1843., godine drži prvi saborski govor na hrvatskom jeziku, protivno stoljetnoj praksi držanja saborskih govora na latinskom jeziku. Taj ključni događaj u konačnici dovodi do uvođenja narodnog jezika u javni život Hrvatske. ${ }^{10}$ Godine 1845. Kukuljević preuzima funkciju velikog suca Varaždinske županije. ${ }^{11}$

\footnotetext{
3 Trenutno je u vitrini izloženo vrijedno bibliofilsko faksimilno izdanje Gutenbergove Biblije izdane oko 1455. godine, temeljeno na primjercima Biblije iz Berlina i Fulde, koji se smatraju najljepšima, a objavio ga je 1961. godine u New Yorku nakladnik "Pageant Books" u tisuću primjeraka.

4 Jakić, Tomislav. O postanku i sastavu biblioteke Ivana Kukuljevića. // Rad Jugoslavenske akademije znanosti i umjetnosti 324, 11(1962), 145-146.

5 Hajduk, Stjepan. Ivan Kukuljević - povjesničar. // Radovi Zavoda za znanstveni rad Varaždin 10-11(1998), 272.

6 Jakić, Tomislav. Nav. dj., str. 146.

7 Isto.

8 Hajduk, Stjepan. Nav. dj., str. 273.

9 Jakić, Tomislav. Nav. dj., str. 146.

10 Kurelac, Miroslav. Ivan Kukuljević Sakcinski - život i djelo. // Radovi Zavoda za znanstveni rad Varaždin 6-7(1994), 102.

11 Jakić, Tomislav. Nav. dj., str. 146.
} 
Kukuljević igra važnu ulogu u političkom životu Hrvatske i revolucionarne 1848. godine, kada se na razne načine zalaže za što povoljniji položaj Hrvatske unutar Monarhije boreći se protiv mađarizacije. ${ }^{12}$ Iste godine ban Josip Jelačić proglašava ga zemaljskim arhivarom ${ }^{13}$ te ga izabire za člana Banskog vijeća, tadašnje privremene hrvatske vlade, gdje ulazi u dva odsjeka - postaje odbornikom zemaljske obrane te predstojnikom odjeljenja za prosvjetu. ${ }^{14}$ Nepovoljan ishod revolucionarnih zbivanja za Hrvatsku i uvođenje nametnutog, tzv. oktroiranog, ustava od strane cara Franje Josipa I., kojim je ojačana centralistička vlast Beča, navodi ga da se povuče sa svoje funkcije u Banskom vijeću te da se odrekne državničke službe i političkog angažmana. ${ }^{15}$

Godine 1860., nakon ukidanja oktoriranog ustava, Kukuljević se vraća u politički život i postaje članom Banske konferencije te radi na obnovi ustavnosti i uređenju uprave hrvatske države, neprestano se zalažući za ujedinjenje Hrvatske i Dalmacije. Od 1861. godine vrši funkciju velikog župana zagrebačkog, a od 1865. do 1867. godine obavlja dužnost banskog namjesnika. ${ }^{16}$ Nakon uvođenja dualizma, tj. nagodbe Austrije s Ugarskom kojom je utemeljena dvojna Austro-Ugarska Monarhija, na temelju čega je Hrvatska u mnogim poslovima postala podložna Ugarskoj, Kukuljević je, zbog svojih političkih pogleda, umirovljen s oba položaja. Nakratko se povlači iz političkog života, no 1870 -ih i 1880-ih ponovno je biran u Hrvatski sabor. ${ }^{17}$ Umire u dvorcu Puhakovec u Hrvatskom zagorju 1. kolovoza 1889. godine. ${ }^{18}$

Iako primarno političar, Ivan Kukuljević Sakcinski ujedno je i književnik, arhivar, biograf, arheolog, povjesničar, povjesničar umjetnosti, povjesničar književnosti, bibliograf, paleograf, izdavač znanstvenih edicija, konzervator, sakupljač povijesne građe i izvora, rijetkih knjiga, kao i usmenog narodnog stvaralaštva. Utemeljio je brojne ustanove od velike važnosti za ravnopravnost Hrvatske, kao i brojne znanstvene discipline. Antun Barac ističe ga kao „najplodnijeg hrvatskog naučnog radnika 19. i 20. vijeka“. ${ }^{19}$

\footnotetext{
12 Kurelac, Miroslav. Nav. dj., str. 103.

13 Lončarević, Magdalena. Ivan Kukuljević Sakcinski i zbivanja 1848./49. u Hrvatskoj. // Historia Varasdiensis : časopis za varaždinsku povjesnicu 1(2011), str. 167.

14 Isto, str. 173.

15 Kurelac, Miroslav. Nav. dj., str. 104.

16 Isto, str. 109.

17 Markus, Tomislav. Ivan Kukuljević u političkom životu Hrvatske 1843.-1867. Prilog istraživanju njegove političke djelatnosti. // Zbornik Odsjeka za povijesne znanosti Zavoda za povijesne i društvene znanosti Hrvatske akademije znanosti i umjetnosti 27(2009), 316-317.

18 Kurelac, Miroslav. Nav. dj., str. 111.

19 Šicel, Miroslav. Književnopovijesni rad Ivana Kukuljevića Sakcinskog. // Radovi Zavoda za znanstveni rad Varaždin 10-11(1988), str. 286.
} 
Kukuljevićev književni rad obuhvaća pjesme, pripovijetke, putopise i dramske tekstove. Godine 1837. dovršava prvo dramsko djelo na štokavskom narječju u sjevernoj Hrvatskoj, Juran i Sofija, ili Turci kod Siska, junačka igra u trih činih, koje tiska u Zagrebu 1839. godine. ${ }^{20}$ Prvi u Hrvatskoj izdaje zbirku hrvatskih narodnih pjesama na sva tri narječja. ${ }^{21}$ Miroslav Šicel smatra kako je njegov najveći doprinos hrvatskoj književnosti u tome što je u korpus hrvatske književnosti uvrstio i latinske pisce. ${ }^{22}$

Iako samouk, bavi se povjesničarskim radom. Jaroslav Šidak Kukuljevića naziva ocem moderne hrvatske historiografije. ${ }^{23} \mathrm{U}$ svojim povijesnim djelima, osim faktografiju i politička zbivanja, u velikoj mjeri proučava i ostala područja povijesti, ekonomsku i pravnu povijest, narodni život i običaje te kulturnu i znanstvenu povijest, koristeći interdisciplinarni pristup..$^{24} \mathrm{Njegov}$ rad na prikupljanju i objavljivanju izvora za hrvatsku povijest daje organizacijsku podlogu hrvatskoj historiografiji. Kako bi pridonio borbi za položaj Hrvatske unutar Habsburške Monarhije i prikazao i dokazao hrvatska povijesna prava, nakon donošenja Listopadske diplome 1861. godine, kojom je nakon razdoblja apsolutističke vlasti vraćen ustavni poredak, izdaje prvi svezak Iura Regni Croatiae, Slavoniae et Dalmatiae, djelo koje je desetljećima služilo pravnicima i političarima. Godine 1863. objavljuje još jednu zbirku hrvatskih srednjovjekovnih javnih i privatnopravnih dokumenata, Acta Croatica. Od 1874. do 1875. godine objavljuje dva sveska Codex diplomaticus regni Croatiae, Dalmatiae et Slavoniae u kojima objavljuje povijesne isprave od 1102. godine do 12. stoljeća. ${ }^{25}$

Kukuljević je i prvi hrvatski znanstvenik bibliograf koji je objavio hrvatsku retrospektivnu bibliografiju, Bibliografiju hrvatsku, 1860. godine. To djelo s približno 3000 bibliografskih jedinica predstavlja do danas temeljni i nezaobilazni bibliografski izvor podataka za stariju hrvatsku književnost, a Kukuljević se u knjižničarskom i bibliografskom svijetu s pravom drži ocem hrvatske bibliografije. ${ }^{26}$ Osobito se posvećuje istraživanju biografija znamenitih Hrvata te je na temelju njegova rada na tom području nastalo i njegovo djelo Književnici u Hrvatah iz prve polovine XVII. vieka s ove strane Velebita. Autor je i opsežne biografske studije o Marku Maruliću. Prikuplja građu i piše priloge iz povijesti umjetnosti, a

\footnotetext{
20 Jakić, Tomislav. Nav. dj., str. 146.

${ }^{21}$ Zvonar, Ivan. Kukuljevićev odnos prema usmenom narodnom stvaralaštvu. // Radovi Zavoda za znanstveni rad Varaždin 8-9(1996), str. 75.

22 Šicel, Miroslav. Nav. dj., str. 289.

23 Hajduk, Stjepan. Nav. dj., str. 280.

24 Kurelac, Miroslav. Nav. dj., str. 106.

25 Hajduk, Stjepan. Nav. dj., str. 273-281.

26 Rogulja, Petar. Dosadašnji rad na hrvatskoj nacionalnoj bibliografiji knjiga. // Građa za hrvatsku retrospektivnu bibliografiju knjiga : 1835.-1940. Knj. 1. A-Bel. Zagreb : Nacionalna i sveučilišna biblioteka, 1982. Str. XXIV.
} 
jedno od najznačajnijih Kukuljevićevih djela s tog područja jest rad objavljen pod naslovom Život Jurja Julija Klovija, slikara te prvi nacionalni biografski leksikon umjetnika Slovnik umjetnikah jugoslavenskih.

Od 1848. do 1861. godine Kukuljević vrši dužnost arhivara Zemaljskog arhiva Hrvatske. Osim što sistematski sređuje arhivsku građu, piše i pravila arhivske službe. Posjećuje brojne arhive u Dalmaciji, Austriji i Mađarskoj te u svojim izvještajima $s$ putovanja daje prikaz fondova i popise rukopisa koji su od velike važnosti za hrvatsku povijest. ${ }^{27}$ Godine 1850 . osniva kulturno-povijesno društvo pod nazivom Družtvo za pověstnicu jugoslavensku ${ }^{28}$ te sljedeće godine pokreće izdavanje organa društva, ujedno prvog hrvatskog znanstvenog i prvog hrvatskog povijesnog časopisa, Arkiva za pověstnicu jugoslavensku. Zaslužan je i za osnivanje i djelovanje djelomičnog nasljednika Družtva, Hrvatskog arkeologičkog društva, kojemu je predsjednik od osnivanja 1878. godine do kraja života. Obavlja i funkciju potpredsjednika Matice ilirske (1851.-1859.) te predsjednika Matice hrvatske (1874.-1889.). ${ }^{29}$ Tadija Smičiklas ističe kako je njegov ugled među suvremenicima bio „toliki, da ga smatrahu najboljim poznavaocem historije hrvatske“ ${ }^{30}$ Član je mnogih europskih društava i akademija, a radi i na osnivanju Jugoslavenske akademije. Među prvima je predložen za Akademijina pravog člana, čast koju u tom trenutku odbija, no prihvaća ju 1886. godine, kada je izabran za počasnog člana. ${ }^{31}$

\section{Knjižnica Ivana Kukuljevića Sakcinskog}

Kukuljevićeva iznimno vrijedna knjižnica sabirana je dugi niz godina. Godine 1867. izjavljuje da se prikupljanjem knjiga počeo baviti još kao časnik u Beču. O svojoj knjižnici kaže: „Knjižnica ova, sastojeća iz preko tisuću rukopisa i do dvanaest tisuća tiskanieh knjiga, te iz više tisuća listina i povelja, sabirana je kroz trideset $\mathrm{i}$ više godina velikim trudom i troškom sadašnjega vlastnika, a sastavljena je sistematički tom namjerom, da bude u njoj po mogućnosti te s veće strane, sve ono, što je budi u pismu, budi u knjigah sačuvano o prošlosti i sadanjem životu južnih Slavena, a osobito Hrvata i Srba. “32

Svoju bogatu zbirku knjiga, dokumenata i rukopisa pribavlja za vrijeme brojnih putovanja, dijelom kupnjom, dijelom darom. Određeni dio knjiga nasljeđuje

\footnotetext{
27 Kurelac, Miroslav. Nav. dj., str. 105.

28 Hajduk, Stjepan. Nav. dj., str. 274-275.

29 Kurelac, Miroslav. Nav. dj., str. 104-108.

30 Smičiklas, Tadija. Život i djela Ivana Kuljevića Sakcinskoga. // Rad Jugoslavenske akademije znanosti i umjetnosti 110, 35(1892), str. 137.

31 Kurelac, Miroslav. Nav. dj., str. 111.

32 Jakić,Tomislav. Nav. dj., str. 155.
} 
od oca Antuna, koji i sam posjeduje knjižnicu u kojoj prevladavaju povijesna djela. Dio građe prikuplja kao član znanstvenih društava i akademija. Većinu knjiga nabavlja na putovanjima po hrvatskim zemljama, Italiji, Štajerskoj, Kranjskoj, Beču, Pešti i Požunu. Njegova najvažnija putovanja, na kojima nalazi najvredniju građu, jesu ona u Dalmaciju. Godine 1854. dva mjeseca boravi u Dalmaciji gdje prikuplja izvore za povijest hrvatskog naroda od dolaska na ova područja do kraja kraljevstva. ${ }^{33}$ U izvještaju s putovanja kaže: „Za tri dana moga bavljenja na otoku Krku sakupio sam ipak do 27 glagoljskih rukopisah, preko 20 tiskanih glagoljskih knjigah, te do 30 glagoljskih listinah., medju kojimi je najstarija od godine $1321 \ldots$ “. ${ }^{\text {34 }} \mathrm{Na}$ Tom putovanju prikuplja gotovo 700 listina i povelja, oko $100 \mathrm{ru}-$ kopisa, među kojima su neki potjecali iz 14., 15. i 16. stoljeća, mnoga povijesna djela, hrvatske knjige te brojne knjige na raznim drugim jezicima. Ta izuzetno velika zbirka rukopisa, knjiga i arhivske građe s najvažnijim dokumentima iz hrvatske povijesti postaje temelj njegove knjižnice.

Godine 1856. odlazi na novo petomjesečno putovanje po Dalmaciji, Albaniji i Italiji. ${ }^{35}$ Biskup Strossmayer, koji mu osigurava sredstva i za prvo putovanje, piše mu: „Vi slobodno na moj račun kupite, ako kake znamenite starine ili na crkveni život ili na umjetnost ili na književnost našu odneseće se nadjete.“" ${ }^{\text {"36 }} \mathrm{Ne}$ zna se točna količinu građe koju prikuplja na tom putovanju, no Smičiklas kaže da je „,njegova biblioteka ... do nevidjene u nas golemosti dospjela iza njegova puta kroz Dalmaciju i Italiju“.37

Osim što posjećuje knjižnice i arhive, uspostavlja brojne kontakte i prijateljstva sa znanstvenicima, književnicima, nakladnicima, knjižarima i antikvarima, koji rezultiraju budućom suradnjom. Mnogi poznanici i prijatelji pomažu mu ući u trag knjigama, kao što mu pomažu i u njihovoj nabavi. Od njih dobiva na dar brojne knjige s posvetama. ${ }^{38}$

Godine 1867. Kukuljević tiska Jugoslavensku knjižnicu Ivana Kukuljevića Sakcinskoga u Zagrebu $u^{39}$, svojevrsni katalog svoje knjižnice, u kojem knjižničnu građu dijeli na tri dijela - rukopise, listine i povelje te tiskane knjige. Tiskane knjige podijelio je u 47 skupina i za svaku je naveo broj knjiga. Zastupljene su knjige iz područja teologije, povijesti, zemljopisa, prava, filozofije, grčkih i rimskih klasika, medicine i vojništva, književnosti, filologije i prirodnih znanosti.

\footnotetext{
33 Isto, str. 148-155.

34 Isto, str. 152.

35 Isto.

36 Smičiklas, Tadija. Nav. dj., str. 154.

37 Isto, 160.

38 Jakić,Tomislav. Nav. dj., str. 150-152.

39 Iste godine tiskano je i izdanje na francuskom jeziku pod naslovom Bibliothèque sud-slave de Jean Kukuljević Sakcinski à Agram.
} 
Najviše su zastupljena područja povijesti, povijesti umjetnosti i starina te hrvatske i staroslavenske knjige. O svojoj zbirci kaže: „U ovom razredu naći ćeš skoro sve knjige i sva tiskana djela, koja se iole tiču povjesti jugoslavenske. ${ }^{“ 40}$ Misal po zakonu rimskoga dvora iz 1483. godine, prva hrvatska tiskana knjiga, najdragocjenije je djelo u njegovoj knjižnici.

Osim knjiga, knjižnica sadrži i 1000 svezaka rukopisa koji se odnose na državnu i kulturnu povijest, prije svega, hrvatskog naroda. Kukuljević ih dijeli na slavenske rukopise te rukopise na stranim jezicima, koji su uglavnom na latinskom i talijanskom. Najznačajniji prikupljeni rukopisi rijetka su ljetopisna djela domaćih i stranih povjesničara koji su pisali o južnim Slavenima, nastala od 15. do 19. stoljeća, od ključne važnosti za povijest hrvatske historiografije, zatim katalozi popisa knjiga i rukopisa, knjige, regeste, povelje, listine, kao i statuti gradova, rukopisi hrvatskih pisaca i glagoljski rukopisi. ${ }^{41}$

Godine 1867. Kukuljević je nakon promjene vlasti umirovljen s časti banskog namjesnika. Zbog neznatne svote koju je dobio za svoju službu, prisiljen je prodati knjižnicu. ${ }^{42}$ Neposredno prije prodaje Akademiji, knjižnica je brojila 12000 jedinica građe. Godine 1868. prodaje knjižnicu Akademiji za 20000 forinti. ${ }^{43} \mathrm{Na}$ taj je način Akademija stekla najveći broj svojih rijetkih i dragocjenih knjiga, niz inkunabula i starih hrvatskih knjiga. ${ }^{44} \mathrm{O}$ njezinoj važnosti i značaju najbolje govore riječi Tomislava Jakića: „,..je Kukuljevićeva biblioteka i po svom knjižnom blagu i po svojoj veličini predstavljala naročito izuzetnu pojavu za svoje vrijeme. Ona nije bila velika i znamenita samo po broju svezaka, nego još više po svom unutarnjem sastavu, koji je bio svjesno, stručno i sistematski popunjavan sa težištem na historiji i književnosti prvenstveno slavenskoj, a zatim i općoj. Takva jedna bogata biblioteka, bogata i po broju knjiga i po njihovu sadržaju, ima već sama po sebi veliko značenje za izgradnju nauke i kulture. ... Kad je Akademija kupila u cijelosti ovu biblioteku, ona ju je na taj način spasila i očuvala za buduća pokoljenja, jer što bi od nje ostalo i gdje bi se sve nalazila, da se pojedinačno ili grupno prodavala ili poklanjala?“45

Danas se Kukuljevićeva ostavština čuva dijelom u Akademijinoj Knjižnici, dijelom u Akademijinu Arhivu. U doba kada je Kukuljević prodao knjižnicu Akademiji, Knjižnica i Arhiv činili su jednu Akademijinu jedinicu. Nakon njihova razdvajanja 1892. godine, Arhiv preuzima rukopisnu građu, dok Knjižnica zadržava Kukuljevićeve knjige.

\footnotetext{
40 Smičiklas, Tadija. Nav. dj., str. 163.

41 Isto, str. 160-162.

42 Jakić,Tomislav. Nav. dj., str. 160.

43 Isto, str. 162.

44 Badalić, Josip. Svečano otvaranje preuređene Knjižnice Jugoslavenske akademije znanosti i umjetnosti. // Ljetopis Jugoslavenske akademije znanosti i umjetnosti 56(1952), str. 217.

45 Jakić, Tomislav. Nav. dj., str. 169.
} 


\subsection{Izložba Ostavština Ivana Kukuljevića Sakcinskog iz Arhiva i Knjižnice Hrvatske akademije znanosti i umjetnosti}

Izložba Ostavština Ivana Kukuljevića Sakcinskog iz Arhiva i Knjižnice Hrvatske akademije znanosti i umjetnosti prati svestranu osobu Ivana Kukuljevića Sakcinskoga kroz 11 vitrina. U 6 vitrina pokušalo se u kronološko-tematskoj strukturi izložbe sažeto prikazati njegov iznimno bogat život i djelovanje, dati pregled njegovih radova na gotovo svim područjima znanosti i umjetnosti, tako da izložene knjige predstavljaju izbor i razvrstane su u sljedeće skupine:

1. Književni i književno-povijesni radovi, putopisi

2. Povijest, kulturna povijest, arheologija, genealogija

3. Povijest umjetnosti, etnologija, epigrafika, enciklopedistika

4. Arhivistika, politika, pravo

5. Bibliografija.

Svaki eksponat popraćen je legendama s biobibliografskim opisom, a pokraj vitrina dan je kronološki popis svih radova iz pojedinog područja. U preostalih 5 vitrina prezentirana je njegova ostavština - rukopisna i knjižna.

Izložba se sastoji od: 1. izložbe rukopisa, 2. izložbe knjiga i 3.10 postera.

\section{Rukopisi}

Arhiv HAZU na ovoj je izložbi s 18 eksponata ${ }^{46}$ predstavio javnosti dio arhivske građe iz osobnog fonda svog počasnog člana. Posjetiteljima su predstavljena pisma iz njegove bogate korespondencije (s Ljudevitom Gajem, Dimitrijom Demetrom, Dragutinom Rakovcem, Bogoslavom Šulekom te tadašnjim predsjednikom Akademije Franjom Račkim), autografi pjesama i rukopis naslovne stranice izvorne povijesne tragedije u 5 činova Marula napisane 1879. godine. Naročito je zanimljiv autografski koncept znamenitog govora što ga je održao na zasjedanju Hrvatskoga sabora 2. svibnja 1843. na hrvatskom jeziku o potrebi uvođenja hrvatskog u javni život, s njegovim vlastoručnim ispravkama u tekstu. Posebno mjesto zauzimaju po prvi put izložene povelje i diplome, koje su Ivanu Kukuljeviću upućene od najznačajnijih znanstvenih i kulturnih institucija i udruga u Hrvatskoj i inozemstvu čiji je bio član, dok je Kukuljevićev privatni život dočaran putem nekoliko listića iz njegova spomenara, nastala između 1835. i 1846., s posvetama njegovih prijatelja na hrvatskom i njemačkom jeziku.

\footnotetext{
46 Zbog izuzetno krhke i osjetljive građe izvornici su digitalizirani i otisnuti na kaširani karton
} A3-formata. 


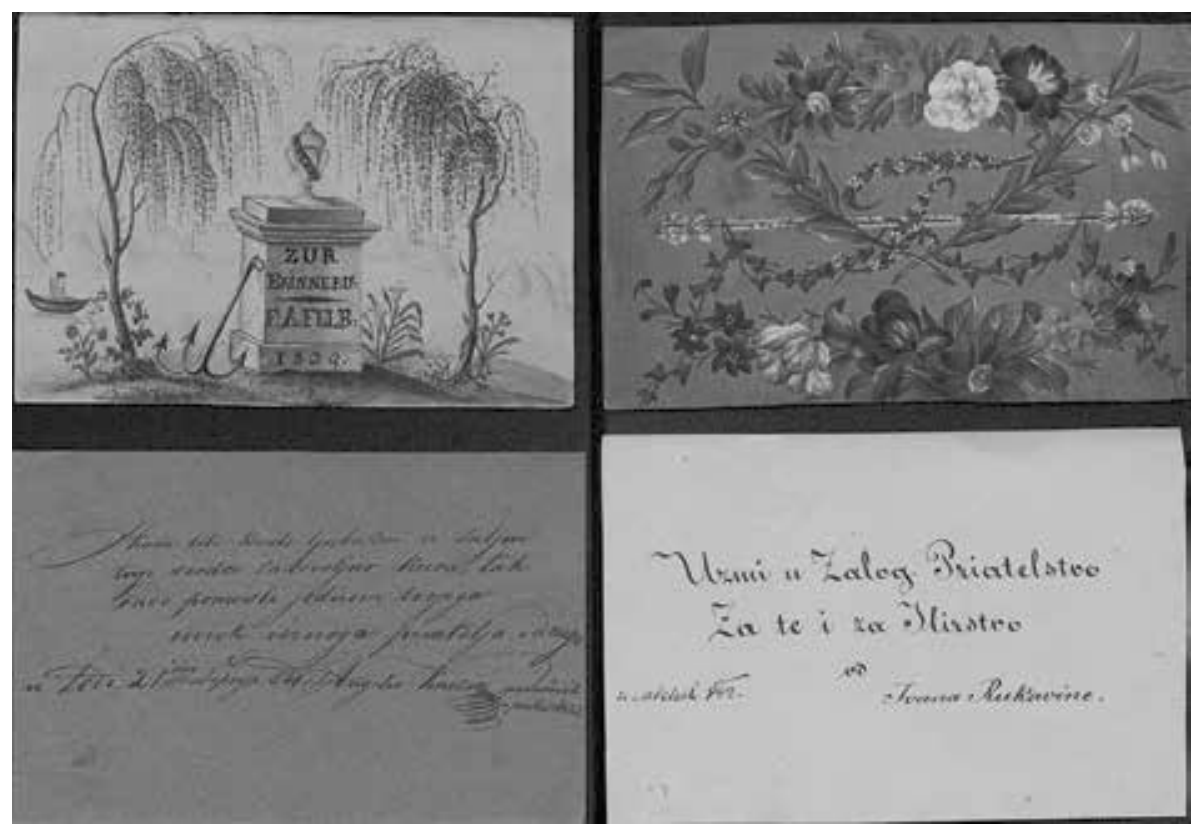

Slika 1. Nekoliko listića iz spomenara Ivana Kukuljevića Sakcinskog iz razdoblja od 1835. do 1846 .

\section{Knjige}

Izložba knjiga s preko 40 primjeraka iz bogatog fonda Knjižnice HAZU koncipirana je u dva dijela. U prvom su dijelu predstavljena neka od Kukuljevićevih najznačajnijih tiskanih djela koja ocrtavaju njegov književni i znanstvenoistraživački rad, dok je drugi dio izložbe posvećen odabranim knjigama iz Kukuljevićeve privatne knjižnice, koje osvjetljavaju njegov lik kao strastvenog bibliofila, sakupljača starih i rijetkih, prije svega hrvatskih, a potom i južnoslavenskih knjiga. Izložene knjige na sebi imaju ekslibrise - njegove autografe, zabilješke o porijeklu knjige ili posvete. Usto, izložena je i knjiga koja je u Knjižnicu HAZU dospjela puno kasnije od strane povjesničara i arhivista Emilija Laszowskog (1868.-1949.), a koja je pripadala Kukuljeviću. Laszowski je na predlistu zabilježio: „16.IX.1942. dobio od gje Tonke Deželić u zamjenu za drugi primjerak“. Radi se o unikatnom, Kukuljevićevom osobnom primjerku Bibliografije hrvat$s k e^{47} \mathrm{u}$ koji su, zajedno s tiskanim izdanjem, uvezani prazni listovi za pisanje bi-

47 Usp. Živković, Janko. Kukuljevićeva Bibliografia hrvatska. // Vjesnik bibliotekara Hrvatske 4, 1-4(1955-57), 83-98. Tom je bibliografijom naime Kukuljević nastojao obuhvatiti sva djela tiskana hrvatskim jezikom od prve hrvatske tiskane knjige 1483. do 1860., odnosno u Dodatku djela tiskana do 1863. Sadrži preko 3100 djela podijeljenih prema pismu u 3 skupine: knjige 
lješki. Listovi su ispisani njegovim vlastoručnim dopunama - natuknicama koje nisu ušle u ovo izdanje.

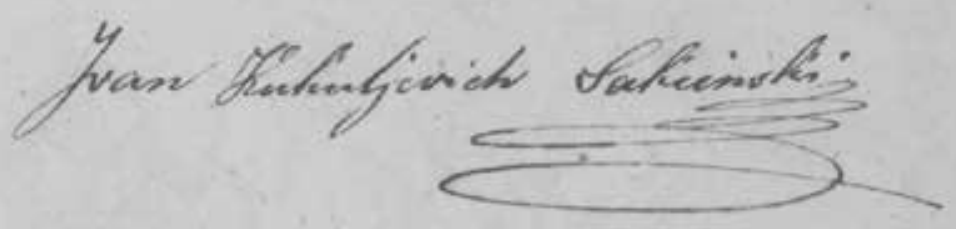

\section{Slika 2. Ekslibris Ivana Kukuljevića Sakcinskog}

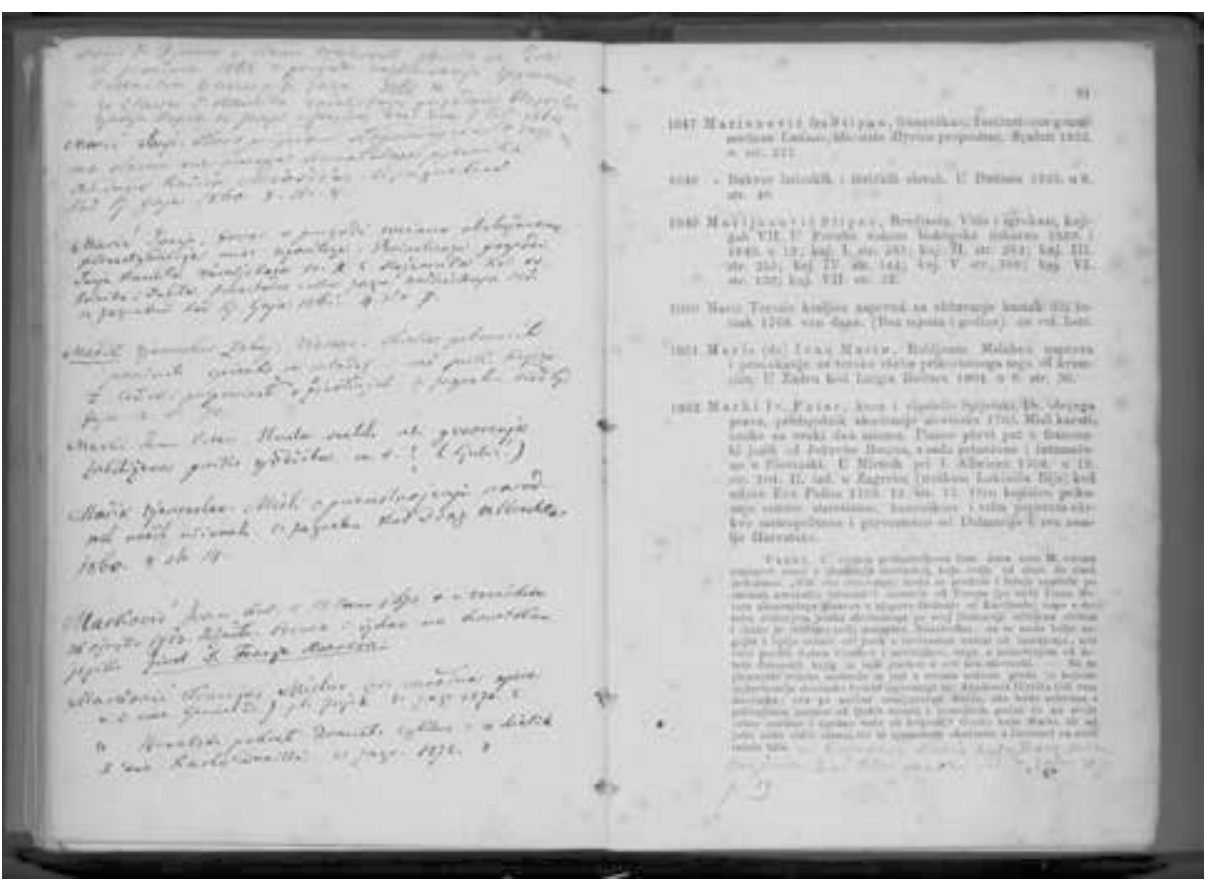

Slika 3. Kukuljevićev osobni primjerak Bibliografije hrvatske

pisane glagoljicom, ćirilicom i latinicom. Trebala je biti samo prva u nizu jugoslavenskih bibliografija, no bibliografija srpska, bugarska i slovenska nisu nikad bile objavljene. Unatoč mnogim nedostacima i nedosljednostima u bibliografskom opisu, ova bibliografija važna je kao prva hrvatska opća retrospektivna bibliografija. 


\section{Posteri}

Izložen je 1 poster s poznatim portretom koji je izradio Josef Mukařovský (1851.-1921.); 1 poster pod naslovom Lik i djelo Ivana Kukuljevića Sakcinskog s područjima njegova djelovanja i doprinosa; 2 postera s kratkim kronološki poredanim crticama iz njegova života ${ }^{48} ; 1$ poster s predbilježnim ugovorom; 1 poster s prikazom njegove privatne knjižnice; 4 postera pod naslovom Ivan Kukuljević $u$ Akademijinim izdanjima s bibliografijom njegovih djela i radova o njemu objavljenih u Akademijinim izdanjima.

Na izložbi je izložen i predbilježni ugovor Jugoslavenske akademije o kupnji knjižnice Ivana Kukuljevića Sakcinskog za 20000 forinti, datiran 5. kolovoza 1868. U čl. 2 toga ugovora navodi se da „Kukuljević daje i prodaje svoju knjižnicu tj. sve knjige svoje, sve rukopise i listine (originale i stare prepise) prema katalogu koji se u njega nahodi, i u kojem je popisana čitava knjižnica na cjedulah..." Taj katalog na listićima danas se čuva u Arhivu HAZU i sastoji se od devet kutija kataložnih listića formata $18,5 \times 12,5 \mathrm{~cm}$ pisanih Kukuljevićevom rukom. Na izložbi je prikazana fotografija tog kataloga i opis sadržaja kako ga je donio Kukuljević.

Izložbom se nastojalo prikazati i kada je i na koji način Kukuljević došao do tako bogate i vrijedne knjižnice. Odgovor su autori izložbe potražili u ekslibrisima koje nalazimo na njegovim knjigama. Izložene knjige svrstane su u šest skupina:

1. Knjige naslijeđene od oca Antuna Kukuljevića ${ }^{49}$ koji je imao veliku knjižnicu pretežno povijesnih djela. Izložena je knjiga Antuna Mažuranića Temelji ilirskoga i latinskoga jezika za početnike (U Zagrebu : Tiskom k. p. nar. ilir. tiskarne dra Ljudevita Gaja, 1839., sign.: 80.531-R), koja na unutarnjoj strani prednjih korica ima rukopisnu posvetu autora Antonu Kukuljeviću na latinskom jeziku: „Magnifico Domino Antonio Kukulyevich aliter Bassani de Sacci, ... , et per Districtum Literarium Zagrabiensem Regio Superiori Studiorum et scholarum Directori / autor".

\footnotetext{
48 Do sada najpotpuniju, najopsežniju i vjerodostojnu bibliografiju Ivana Kukuljevića Sakcinskoga napisao je Tadija Smičiklas (1843.-1914.), povjesničar i političar, a objavljena je 1892. god. u Radu JAZU 110(1892), 110-204 pod naslovom Život i djela Ivana Kukuljevića Sakcinskoga.

49 Antun Kukuljević Sakcinski (1776.-1851.), hrvatski političar i kulturni djelatnik, podžupan Varaždinske županije i hrvatski zastupnik u zajedničkom hrvatsko-ugarskom saboru u Požunu (1832.-1836.), vrhovni ravnatelj škola u Hrvatskoj (1836.-1847.). Bio je i ravnatelj Hrvatskoga glazbenoga zavoda, a njegovim su nastojanjem otvorene mnogobrojne obrazovne ustanove $u$ Hrvatskoj. Oštro se suprotstavljao uvođenju mađarskog jezika u hrvatske škole.
} 


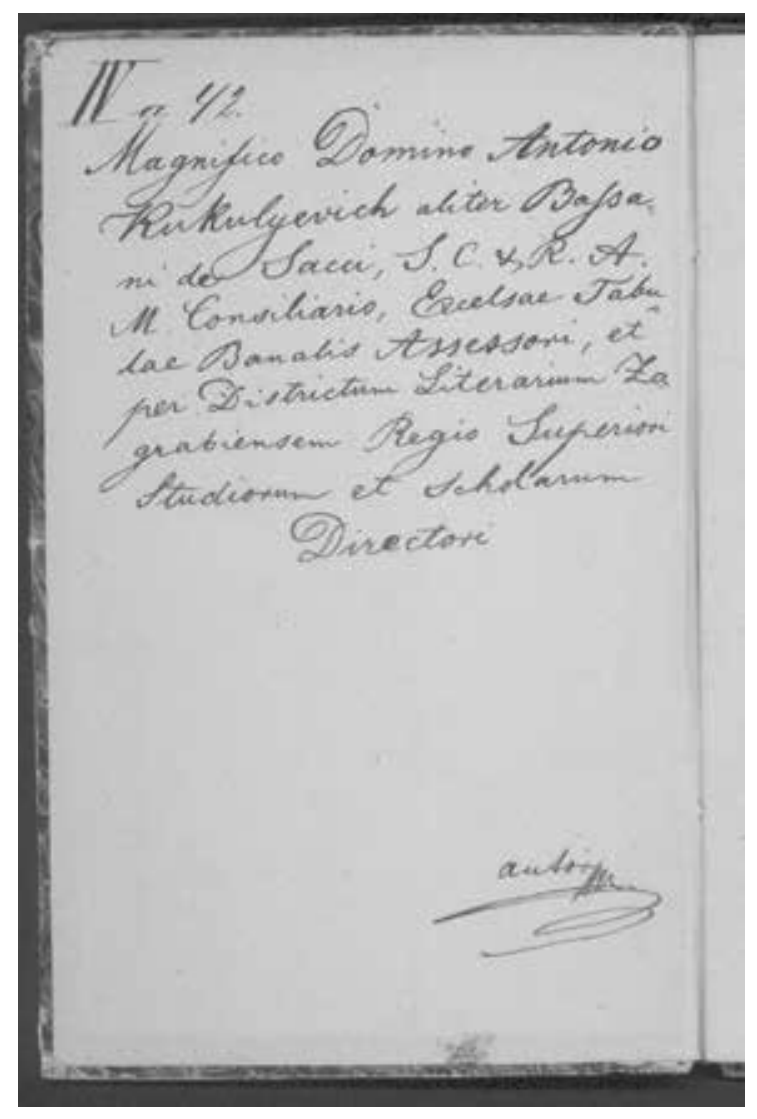

Slika 4. Knjiga s posvetom autora Antunu Kukuljeviću

2. Mladi Kukuljević, tj. knjige koje je Kukuljević sabrao već kao mladi časnik ugarske garde za svoga boravka u Beču (1835.-1840.) i Milanu (1841.). Većinom su to povijesna i književna djela, a na knjigama redovito nalazimo njegov vlastoručni potpis s dodatkom „Garde Lieutnant, Locumtenentis Lieutenant, Ltnt, Garde Ltnt, Pod-Naručnik i sl.“

Izložena je knjiga Vjekoslava Babukića Osnova slovnice slavjanske narěčja ilirskoga (U Zagrebu, s.a., sign.: R-1493). Na knjizi se nalazi njegov vlastoručni potpis s dodatkom „Naručnik“"

3. Knjige s Kukuljevićevim vlastoručnim potpisima (u raznim grafijama), zanimljive iz razloga što se Kukuljević običavao potpisivati na raznim jezicima, ovisno o tome na kojem je jeziku napisana knjiga. Tako npr. nalazimo njegov potpis na njemačkom jeziku ,Johann von Kukuljevich“, na latinskom jeziku 
„Ex bibliotheca Johannis Kukuljević de Sacci“, na talijanskom jeziku „Giovani Kukuljević de Sacci“, na ćirilici itd. Izloženo je nekoliko takvih knjiga.

4. Knjige s naljepnicom (stampata) i zapisom u strojopisu: Br._Kukuljević, na kojima se naljepnica redovito nalazi na naslovnom listu i vjerojatno je nalijepljena mnogo kasnije u Knjižnici JAZU s namjerom označavanja i evidentiranja njegovih knjiga unutar ostalog fonda, no nikada nije provedena do kraja. Evidentiran je relativno mali broj takvih knjiga.

5. Knjige s vlastoručnim Kukuljevićevim marginalijama i zabilješkama o načinu nabave i porijeklu knjige, vrlo zanimljive jer nam govore mnogo o tome na koje je sve načine Kukuljević dolazio do knjiga, kao i o osobama s kojima je bio u kontaktu. Tu su knjige koje je dobio na dar, zatim naročito vrijedne knjige koje je nabavljao kod antikvara. Kao primjer izložena je knjiga Grge Čevapovića Josip, sin Jakoba patriarke iz 1820. (sign. R-1040). Na predlistu se nalaze čak dva rukopisna zapisa; prvi, stariji, na latinskom jeziku, koji kaže da je Antun Mihanović dobio knjigu na dar od biskupa Vrhovca 1821. god. i drugi od Ivana Kukuljevića: 1. „Ab Exmo Eppo Werhowacz dono acceptus - Mihanovich. Zagrabiae 18. Nov. [1]821“; 2. „Ovu knjigu kupio sam kod antikvara Kupića u Beču g. 1867. kamo ju proda zet Mihanovićev / Kukuljević“". Ili na inkunabuli iz 1478. god., gdje na predlistu piše: „Kupljena je rědka ova knjiga po meni 24. listopada 1848 u Gorici (i.e. Görtz) medju drugimi starimi knjigami, koje kako okolnosti svedoče ondešnji knjigar Paternoli dobi iz knjižnice grofovah Koroniniah / Ivan Kukuljević“".

6. Knjige s vlastoručnim posvetama Kukuljeviću, bilo autora, urednika ili pak njegovih prijatelja. Te su knjige dosta zastupljene unutar zbirke, najraznovrsnijeg su sadržaja i pružaju nam pogled na širok krug ljudi koje je Kukuljević poznavao, s kojima se družio, razmjenjivao misli i ideje. Pokazuju također i kako je velik društveni i politički ugled Kukuljević uživao u zemlji i inozemstvu - posvete su to koje izražavaju prijateljstvo i duboko poštovanje prema njemu. Tako mu npr. Jan Šafařík ${ }^{50}$ posvećuje svoju disertaciju iz 1838. god. riječima: „Blagorodnomu i veleučenomu gospodinu Ivanu Kukuljeviću Sakcinskomu, pl. tit. verlomu i mnogopoštovanumu domorodcu i iskrenomu Slavjanu na znak svoga poštovanja i ljubavi bratske uzajamno slavinske priatel i cěnitelj, pobratim Slovak Janko Dragutin Šafarik, doktor lekarstva." Ovu izložbu prati i deplijan koji su posjetitelji mogli ponijeti sa sobom nakon razgledavanja izložbe.

50 Pavao Josef Šafařík (1795.-1861.) bio je slovački pisac, povjesničar i lingvist koji je svoje radove pisao na češkom ili njemačkom. Postao je međunarodno priznati autoritet i jedan od utemeljitelja znanstvene slavistike te promicatelj slavenske uzajamnosti. Održavao je veze sa širokim krugom književnika i znanstvenika svojega doba, također i s hrvatskim ilircima (Lj. Gajem, I. Kukuljevićem i ost.). Objavio je 1826. god. Povijest slavenskoga jezika i književnosti prema svim narječjima na njem. jeziku. Napisao je i Povijest južnoslavenske književnosti (Geschichte der südslawischen Literatur, I-III, 1864-65). 
Vjesnik bibliotekara Hrvatske 60, 1(2017), 47-64

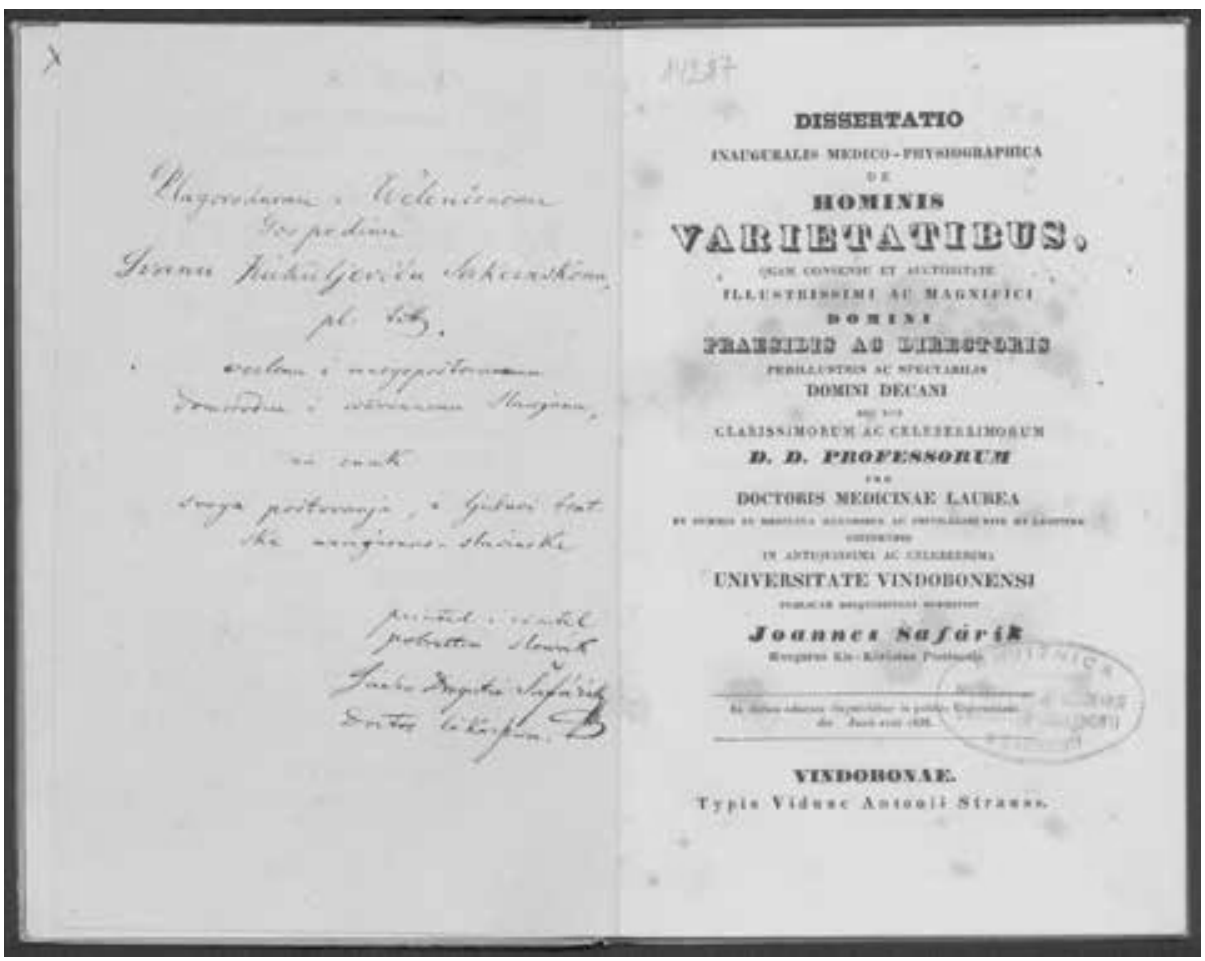

Slika 5. Knjiga s posvetom Jana Šafaříka Ivanu Kukuljeviću

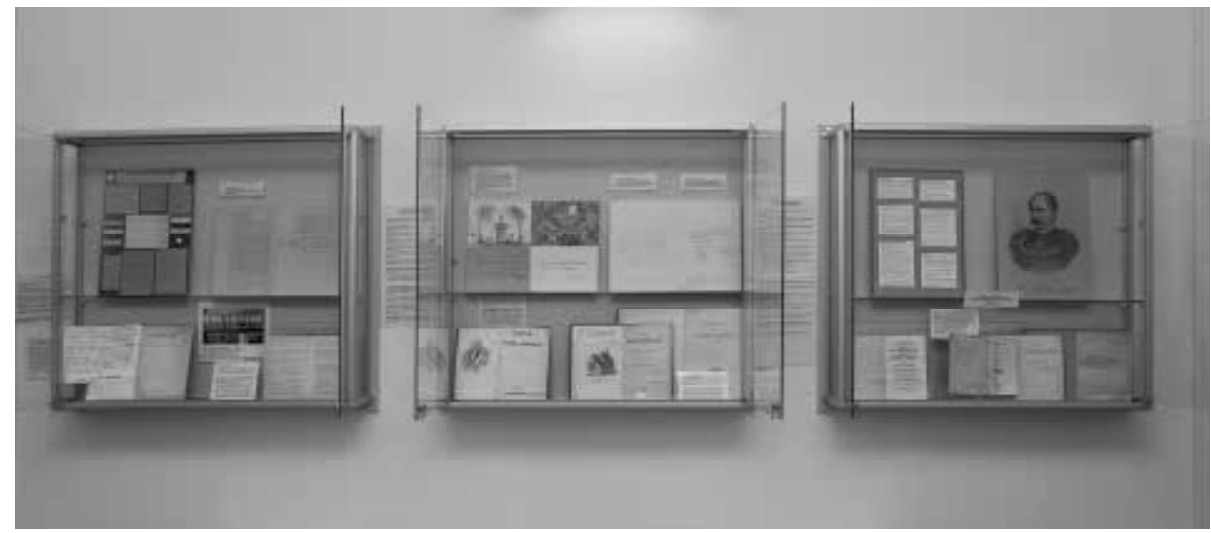

Slika 6. Izložbene vitrine u Knjižnici HAZU 


\section{Zaključak}

Izložba Ostavština Ivana Kukuljevića Sakcinskog iz Arhiva i Knjižnice HAZU, o kojoj se moglo doznati više na mrežnim stranicama i Facebooku Knjižnice HAZU, privukla je brojne posjetitelje. Među njima je zabilježen sve veći broj skupina učenika i studenata, pa zaključujemo da je dobro da se u prostorima znanstvene knjižnice priređuju izložbe knjiga, jer na taj način znanstvena knjižnica izlazi iz okvira svoje primarne zadaće služenja matičnoj akademskoj i znanstvenoj zajednici te se još više otvara široj javnosti djelujući na nju edukativno, istodobno promičući hrvatsku znanost i kulturu. Akademijina je Knjižnica otvorena za najšire skupine korisnika, a putem ove izložbe stekla je i brojne nove članove, posjetitelje izložbe, koji su se prigodom razgledavanja ostavštine Ivana Kukuljevića Sakcinskog upoznali s njezinim prostorom i zbirkama. ${ }^{51}$

\section{LITERATURA}

Badalić, Josip. Svečano otvaranje preuređene Knjižnice Jugoslavenske akademije znanosti i umjetnosti. // Ljetopis Jugoslavenske akademije znanosti i umjetnosti 56(1952), 204-223.

Coplan, Kate. Effective library exhibits : how to prepare and promote good displays. New York, NY: Oceana publications, 1958.

Hajduk, Stjepan. Ivan Kukuljević - povjesničar. // Radovi Zavoda za znanstveni rad Varaždin 10-11(1998), 271-283.

Jakić, Tomislav. O postanku i sastavu biblioteke Ivana Kukuljevića : prilog historijatu Knjižnice Jugoslavenske akademije znanosti i umjetnosti. // Rad Jugoslavenske akademije znanosti i umjetnosti 324, 11(1962), 145-170.

Knjižnica. // Ljetopis Hrvatske akademije znanosti i umjetnosti : Knj. 120 : za godinu 2016. / ur. Pavao Rudan. Zagreb : Hrvatska akademija znanosti i umjetnosti, 2017. Str. 634-643.

Kurelac, Miroslav. Ivan Kukuljević Sakcinski - život i djelo. // Radovi Zavoda za znanstveni rad Varaždin 6-7(1994), 101-116.

Lončarević, Magdalena. Ivan Kukuljević Sakcinski i zbivanja 1848./49. u Hrvatskoj. // Historia Varasdiensis : časopis za varaždinsku povjesnicu 1(2011), 167-182.

Markus, Tomislav. Ivan Kukuljević u političkom životu Hrvatske 1843.-1867. Prilog istraživanju njegove političke djelatnosti. // Zbornik Odsjeka za povijesne znanosti

51 Knjižnica. // Ljetopis Hrvatske akademije znanosti i umjetnosti : Knj. 120 : za godinu 2016. / ur. Pavao Rudan. Zagreb : Hrvatska akademija znanosti i umjetnosti, 2017. Str. 636. 
Zavoda za povijesne i društvene znanosti Hrvatske akademije znanosti i umjetnosti 27(2009), 293-318.

Maroević, Ivo. Uvod u muzeologiju. Zagreb : Filozofski fakultet Sveučilišta, Zavod za informacijske studije Odsjeka za informacijske znanosti, 1993.

Rogulja, Petar. Dosadašnji rad na hrvatskoj nacionalnoj bibliografiji knjiga. // Građa za hrvatsku retrospektivnu bibliografiju knjiga : 1835.-1940. Knj. 1. A-Bel. Zagreb : Nacionalna i sveučilišna biblioteka, 1982. Str. XV-XXXII.

Smičiklas, Tadija. Život i djela Ivana Kuljevića Sakcinskoga. // Rad Jugoslavenske akademije znanosti i umjetnosti 110, 35(1892), 110-204.

Šicel, Miroslav. Književnopovijesni rad Ivana Kukuljevića Sakcinskog. // Radovi zavoda za znanstveni rad Varaždin 10-11(1988), 285-291.

Zvonar, Ivan. Kukuljevićev odnos prema usmenom narodnom stvaralaštvu. // Radovi Zavoda za znanstveni rad Varaždin 8-9(1996), 75-84.

Živković, Janko. Kukuljevićeva Bibliografia hrvatska. // Vjesnik bibliotekara Hrvatske 4, 1-4(1955-57), 83-98. 